\title{
Perilaku Seksual Pranikah Anak Jalanan Tahun 2017
}

\author{
Siti Rahmadani \\ Jurusan Kebidanan Poltekkes Kemenkes Jakarta I \\ Email : aksarahmadani@gmail.com
}

\begin{abstract}
Abstrak
Anak jalanan merupakan kelompok yang rentan dalam melakukan perilaku beresiko dan sebagian besar anak jalanan tergolong dalam kategori remaja sehingga hal ini menjadi masalah yang sangat penting dalam perilaku beresiko pada remaja.Perilaku seksual merupakan perilaku yang bertujuan untuk menarik perhatian lawan jenis dan terkait dengan aktivitas hubungan seksual yang dilakukan dalam upaya memenuhi dorongan seksual. Tujuan umum penelitian ini mengetahui faktor-faktor personal dan lingkungan terhadap anak jalanan tahun 2017. Desain penelitian bersifat deskriptif kuantitatif dengan pendekatan cross sectional dan melakukan wawancara pada anak anak jalanan. Instrument penelitian ini mengunakan kuesioner terstruktur sesuai dengan variabel yang diteliti dengan mengunakan kuesioner terstruktur sesuai dengan variabel yang diteliti dengan mengunakan data primer. Data yang terkumpul di analisis secara univariat, bivariate dan multivariat. Uji statistik mengunakan uji chi-Square . Lokasi yang digunakan sekolah Philosophia Foundation .Sampel penelitian adalah total populasi yaitun anak-anak jalanan di sekolah philosophia Foundation Pada Tahun 2017. Hasil penelitian menunjukkan bahwa ada 2 variabel yang berhubungan yaitu umur dan pengetahuan dan faktor lingkungan ditemukan ada 1 variabel keterpaparan pornografi dengan perilaku seksual pranikah pada anak jakanan. Faktor yang paling dominan berpengaruh adalah keterpaparan media pornografi dengan p-value 0.000 dengan OR dengan perilaku seksual pranikah pada anak jalanan. Berdasarkan hasil penelitian, disarankan membentuk pelayanan kesehatan peduli remaja untuk mengatasi masalah kesehatan reproduksi remaja dan menjadi rujukan pada remaja yang menyimpang. Diharapkan anak jalanan meningkatkan upaya promotip dan preventip dalam bentuk penyuluhan kesehatan reproduksi pada remaja dan kegiatan peergroup untuk pendidikan untuk pendidikan kesehatan reproduksi sejak dini.
\end{abstract}

Street Children are vulnerable groups in carrying out risky behavior and most street children belong to the category of adolescents so that this becomes a very important problem in risky behavior in adolescents.behavior Sexualis a behavior that aims to attract the opposite sex and activity related to sexual relations conducted in an effort to satisfy sexual urges. The general purpose of this study is to find out the personal and environmental factors of street children sexual behavior in 2017. The research design is descriptive quantitative with a cross sectional approach and interviews with street children. This research instrument uses a structured questionnaire in accordance with the variables studied using primary data. The collected data were analyzed by univariate, bivariate and multivariate. Statistical test uses Chi Square test. Location used at the Philosophia Foundation School. The study sample with a total population of street children at the Philosophia Foundation School in 2017. The results showed that there were 2 personal variables related to age factors and knowledge and environmental factors found there was 1 variable pornography exposure to premarital sexual behavior on street children. The most dominant factor influencing environmental factors in terms of exposure to pornographic media with p-value 0,000 with OR 2,654 with premarital sexual behavior on street children. Based on the results of the study, it is recommended to form adolescent care health services to overcome adolescent reproductive health problems and be a reference for deviant adolescents. It is expected that street children will increase promotive and preventive efforts in the form of reproductive health counseling on adolescents and peer group activities for early reproductive health education.

Keywords: Premarital sexual behavior

Kata kunci: perilaku sex pra nikah Abstract 


\section{Pendahuluan}

Masa remaja adalah masa dimana perubahan fisik, mental, dan sosial ekonomi terjadi. Secara fisik terjadi perubahan karakteristik jenis kelamin sekunder menuju kematangan seksual dan reproduksi (WHO, 2006). Masalah yang berkaitan dengan reproduksi remaja seperti bertambahnya kasus Infeksi Menular Seksual, merebaknya kasus aborsi akibat kehamilan yang tidak diinginkan, dan kecenderungan remaja melakukan hubungan seks pranikah ( Pratiwi dan Basuki, 2010).

Perilaku seksual merupakan perilaku yang bertujuan untuk menarik perhatian lawan jenis dan terkait dengan aktivitas hubungan seksual yang dilakukan dalam upaya memenuhi dorongan seksual. Perilaku seksual beresiko merupakan aktivitas seksual yang beresiko mengancam kesehatan seseorang akibat terpaparnya berbagai macam penyakit yang dapat ditularkan melalui hubungan seksual. Aktivitas seksual yang termasuk kedalam perilaku seksual berisiko antara lain berciuman, menyentuh payudara, menyentuh sekitar alat kelamin, menyentuh alat kelamin, melakukan oral sex, anal sex, atau vaginal sex ( Fortenberry, 2011).

\section{Metode}

Desain penelitian yang digunakan adalah penelitian yang bersifat deskriptif kuantitatif dengan rancangan studi potong lintang (cross sectional) pada anak jalanan umur 12-16 tahun.

\section{Hasil}

Tabel 1 Distribusi frekwensi Responden berdasarkan faktor personal dan lingkungan dengan Perilaku Seksual Pranikah pada anak jalanan di Depok tahun 2017

\begin{tabular}{ll}
\hline Variabel Independen & $\mathrm{F}(\%)$ \\
\hline Faktor Personal & \\
Umur & $30(29.7 \%)$ \\
$<13$ tahun & $71(70.3 \%)$ \\
$>13$ Tahun & \\
Jenis Kelamin & $50(49.5 \%)$ \\
Perempuan & $51(50,5 \%)$ \\
Laki-laki & \\
Pengetahuan & $56(55,4 \%)$ \\
Kurang baik & $45(44,6 \%)$ \\
Baik &
\end{tabular}

Dari tabel di atas dapat dilihat dari umur, jeni kelamin dari faktor personal terhadap perilaku seksual pada anak jalanan adalah umur $>13$ tahun sebesar 71 orang $(70.3 \%)$ dan jenis kelamin laki-laki sebanyak 51 orang dan pemahaman tentang kesehatan reproduksi meliputi tumbuh kembang, seks pranikah dan perilaku seksual berisiko yang kurang baik sebanyak 56 responden $(55,4 \%)$ 
Tabel 2 Hubungan Faktor Personal dan Lingkungan Terhadap Perilaku Seksual Pranikah Pada Anak Jalanan di Depok Tahun 2017.

\begin{tabular}{lc}
\hline \multicolumn{1}{c}{ Variabel } & p-value \\
\hline & \\
Umur * & 0.047 \\
Jenis kelamin & 0.778 \\
Pengetahuan & 0.606 \\
Pubertas* & 0.034 \\
Keterpaparan Pornografi * & 0.025 \\
Komunikasi Orang tua & 0.908 \\
Komunikasi teman sebaya* & 0.148 \\
\hline
\end{tabular}

Dari 7 variabel ditemukan hanya 4 variabel yang memenuhi syarat masuk model multivariate dengan $p$ value $<0,25$ dari faktor personal adalah variable umur, pubertas. Faktor Lingkungan adalah keterpaparan pornografi dan komunikasi teman sebaya .

\begin{tabular}{lcllll} 
Tabel 5.6 & \multicolumn{6}{c}{ Model Akhir Multivariat } & & \\
\hline \multicolumn{1}{c}{ Variabel Independen } & Koefisien & S.E & P-value & OR & 95\% CI \\
\hline Keterpaparan Pornografi & 0.976 & 0.443 & 0.027 & 2.654 & $1.115-6.318$ \\
Konstanta & -1.264 & 0.314 & 0.000 & & \\
& & & & &
\end{tabular}

Dari tabel di atas dapat dilihat bahwa Koefisien sebesar 0.976, dapat diartikan keterpaparan Media pornografi sebesar 97,6\% berhubungan dengan perilaku anak jalanan . Nilai $\mathrm{P}$ value 0.000 berarti ada hubungan keterpaparan media pornografi terhadap perilaku seksual pada anak jalanan.

\section{Pembahasaan}

Hasil dari uji statistik di dapatkan $\mathrm{p}$ value sebesar $0.47<0.05$ artinya adanya hubungan antara umur responden dengan perilaku seksual pranikah dan OR sebesarnya 2.889 artinya responden yang berusia $>13$ tahun memiliki 2.889 kali lebih besar untuk melakukan perilaku seksual pranikah dibandingkan dengan responden $<13$ tahun.Hal ini sesuai dengan penelitian yang dilakukan Rakhwati (2013) dan Sumarwati (2014) bahwa umur memiliki hubungan yang signifikan dengan perilaku seksual.

Hasil dari uji statistik didapatkan $\mathrm{p}$ value $0.034 \mathrm{~b}<0,05$ artinya adanya hubungan pubertas dengan perilaku seksual pranikah.Dari OR sebesar 4.651 artinya responden yang sudah puber risiko 4,651 kali lebih besar untuk melakukan perilaku seksual pranikah dibandingkan responden yang belum puber.Hal ini sesuai dengan Sumarwati (2014) ada hubungan antara pubertas dengan perilaku seksual anak jalanan berisiko 8.5 kali beresiko dibandingkan dengan yang belum pubertas.

Faktor keterpaparan media pornografi dilihat dari anak jalanan yang terpapar media pornografi yang berisiko dengan $\mathrm{p}$ value sebesar $0.025<0.05$ artinya ada hubungan keterpaparan media pornografi dengan perilaku seksual pranikah.Dari OR 2,654 artinya 2,654 kali lebih besar untuk melakukan perilaku seksual pranikah dibandingkan dengan responden yang tidak terpapar. Berdasarkan hasil penelitian media cetak yang paling banyak adalah komik.Hal ini sesuai 
dengan penelitian Sumarwati (2014) bahwa adanya hubungan keterpaparan media pornografi dengan perilaku seksual memiliki 6 kali peluang untuk melakukan perilaku seksual dibanding yang tidak terpapar.

\section{Kesimpulan}

1. Faktor Personal yaitu umur dan pubertas memiliki hubungan yang bermakna terhadap perilaku seksual pranikah pada anak jalanan di depok tahun 2017

2. Faktor Lingkungan yaitu keterpaparan pornografi memiliki hubungan yang bermakna terhadap perilaku seksual pranikah pada anak jalanan di depok tahun 2017

3. Perilaku seksual pranikah anak jalanan di depok faktor yang paling dominan adalah faktor segi keterpaparan media pornografi dengan $\mathrm{p}$ value 0.000 dengan OR 2.654.

\section{DAFTAR PUSTAKA}

1. Fortenberry, et all. (2011). Human Sexuality from Cell to Society. Belmont, CA: Wadsworth

2. Green, Lawrance, Marshall Kreuter. (2005). Health Program Planing: an Educational and Ekological Approach for Edition 4. The McGraw-Hill company

3. Hurlock. (2004). Psikologi Perkembangan Suatu Pendekatan Sepanjang Rentang Kehidupan Edisi Kelima. Yogyakarta: Erlangga

4. Kementerian Kesehatan. (2011). Modul Pelatihan Pelayanan Kesehatan Peduli Remaja (PKPR) bagi Tenaga Kesehatan. Jakarta: Kementerian Kesehatan RI

5. Mariani, Ani., Bachtiar, Imam. (2010). Keterpaparan Materi Pornografi dan Perilaku Seksual Siswa Sekolah Menengah Pertama Negeri. Makara, Sosial Humaniora, Vol 14, No.2, Desember 2010:83-90

6. Notoatmodjo, Soekidjo. (2010). Metodologi Penelitian Kesehatan. Jakarta: Rineka Cipta

7. Maryatun, Wahyu P. (2012). Hubungan Pengetahuan dan Peran Keluarga dengan Perilaku Seksual Pranikah pada Remaja Anak Jalanan di Kota Surakarta. Gaster, 9, 22-29

8. SDKI. (2012). Survei Demografi dan Kesehatan Indonesia 2012 Kesehatan Reproduksi Remaja. Jakarta: Kementrian Kesehatan RI

\section{Saran}

1. Membentuk pelayanan kesehatan peduli remaja untuk mengatasi masalah kesehatan reproduksi remaja dan menjadi rujukan pada remaja yang menyimpang

2. Meningkatakan upaya promotip dan preventip dalam bentuk penyuluhan kesehatan reproduksi pada remaja

3. Melakukan kegiatan peer group sebagai sarana unruk melakukan pendidikan kesehatan reproduksi sejak dini.

4. Perlunya monitoring orang tua terhadap waktu penggunaan gadget siswa disekolah maupun dirumah

5. Perlunya informasi dari pihak sekolah dan orang tua tentang dampak positif dan negatif dari penggunaan gadget. 